Institute of $\mathbf{F}_{\text {ood and }} \mathbf{A}_{\text {gricultural }} \mathbf{S}_{\text {ciences }}$

\title{
Imported Cabbageworm, Pieris rapae (Linnaeus) (Insecta: Lepidoptera: Pieridae) ${ }^{1}$
}

J. L. Capinera ${ }^{2}$

\section{Distribution}

The imported cabbageworm occurs in temperate regions around the world, and was first observed in North America in 1860 at Quebec City, Canada. It dispersed rapidly, and by 1886 was found in the Gulf Coast and Rocky Mountain states. It is now widespread in North America although few cabbageworms reportedly survive the winter in most of Canada.

Pieris rapae is easily confused with other common cabbage white butterflies: Pontia protodice, southern cabbageworm; Pieris napi, mustard white; and Ascia monuste (Linnaeus), the southern white. Prior to introduction of the imported cabbageworm, Pieris napi (Linnaeus) was the dominant cabbage butterfly in the north, and Pontia protodice (Boisduval \& LeConte) was the principal cabbage-feeding butterfly in the south. Both have been largely replaced by $P$. rapae, although they sometimes co-occur on cultivated crucifers or on weeds.

\section{Life Cycle and Description}

The complete life cycle of this insect requires three to six weeks, depending on weather. The number of generations reported annually is two to three in Canada, three in the New England states, three to five in California, and six to eight in the south. Imported cabbageworm can be found throughout the year in Florida.

\section{Egg}

Eggs are laid singly, usually on the lower surface of outer leaves of plants. The egg measures $0.5 \mathrm{~mm}$ in width and $1.0 \mathrm{~mm}$ in length, and initially is pale white in color but eventually turns yellowish. The egg is laid on end, with the point of attachment flattened and the distal end tapering to a blunt point. The shape is sometimes described as resembling a bullet.

\section{Larva}

The larva is green, velvety in appearance, and bears five pairs of prolegs. There are five instars. Head capsule widths are about 0.4, 0.6, 0.97, 1.5, and $2.2 \mathrm{~mm}$, respectively. Body lengths at maturity of

1. This document is EENY-126 one of a series of Featured Creatures from the Entomology and Nematology Department, Florida Cooperative Extension Service, Institute of Food and Agricultural Sciences, University of Florida. Published: March 2000. This document is also available on Featured Creatures Website at http://creatures.ifas.ufl.edu. Please visit the EDIS Website at http://edis.ifas.ufl.edu. Additional information on these organisms, including many color photographs, is available at the Entomology and Nematology Department website at http://entnemdept.ifas.ufl.edu/.

2. J. L. Capinera, professor/chairman, Entomology and Nematology Department, Cooperative Extension Service, Institute of Food and Agricultural Sciences, University of Florida, Gainesville, FL 32611.

The Institute of Food and Agricultural Sciences is an equal opportunity/affirmative action employer authorized to provide research, educational information and other services only to individuals and institutions that function without regard to race, color, sex, age, handicap, or national origin. For information on obtaining other extension publications, contact your county Cooperative Extension Service office. Florida Cooperative Extension Service/Institute of Food and Agricultural Sciences/University of Florida/Christine Taylor Waddill, Dean. 
each instar averages 3.2, 8.8, 14.0, 20.2, and 30.1 $\mathrm{mm}$, respectively. The larva requires about 15 days (range 11 to 33 days) to complete its development during August. Average (and range) of development times for each instar at 19 degrees $C$ was observed to be 4.5 (2.5-6), 3.0 (1.5-5), 3.3 (2-5), 4.1 (3-6.5), and 7.8 (5-18) days, respectively. All larval stages except the first instar bear a narrow yellow line running along the center of the back; this stripe is sometimes incomplete on the early instars. A broken yellow line, or series of yellow spots, also occurs on each side.

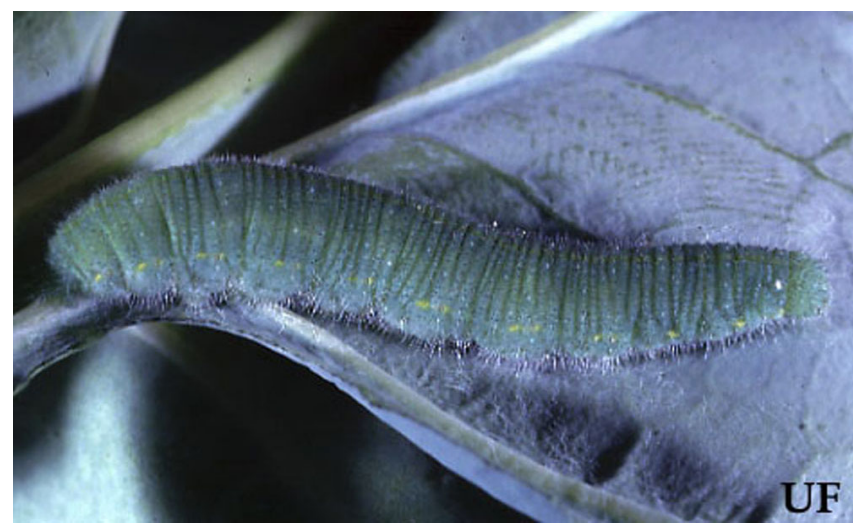

Figure 1. Larva of imported cabbageworm, Pieris rapae (Linnaeus). Credits: J. L. Capinera, University of Florida

\section{Pupa}

Pupation normally occurs on the food plant, but cabbageworm may pupate in nearby debris. The chrysalis is about 18 to $20 \mathrm{~mm}$ in length, and varies in color, usually yellow, gray, green and speckled brown. A sharply angled, keel-like projection is evident dorsally on the thorax, and dorsolaterally on each side of the abdomen. At pupation, the chrysalis is anchored by the tip of the abdomen to the silk pad, and a strand of silk is loosely spun around the thorax. Pupation during the summer generations lasts about 11 days. The chrysalis is the overwintering stage, however, so its duration may be prolonged for months. The proportion of pupae that diapause increases as autumn progresses, so that at the time of the final generation all pupae are in diapause.

\section{Adult}

Upon emergence from the chrysalis the butterfly has a wing span of about 4.5 to $6.5 \mathrm{~cm}$. It is white above with black at the tips of the forewings. The front wings are also marked with black dots: two in the central area of each forewing in the female, and one in case of males. When viewed from below, the wings generally are yellowish, and the black spots usually show faintly through the wings. The hind wing of each sex also bears a black spot on the anterior edge. The body of the butterfly is covered with dense hair, which is colored white in females, but darker in males. The adult typically lives about three weeks. The female produces 300-400 eggs. The adult is very active during the daylight hours, often moving from the crop to flowering weeds to feed.

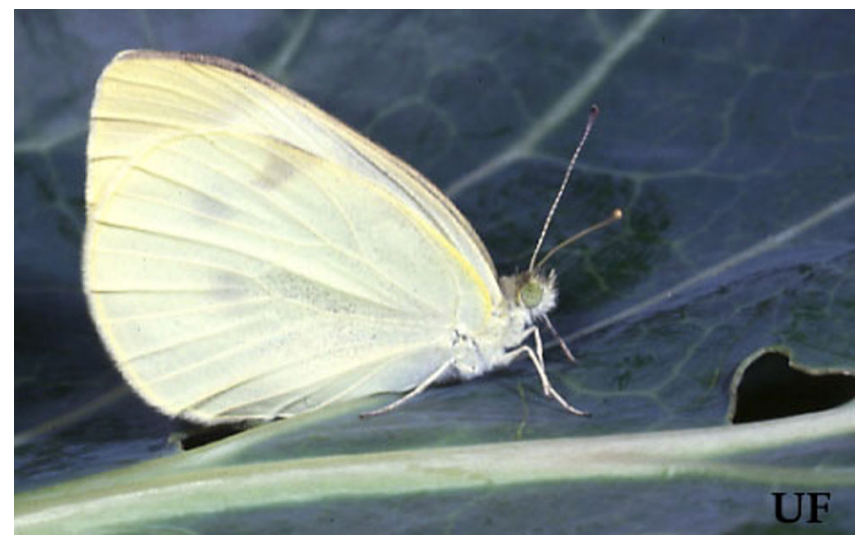

Figure 2. Adult of the imported cabbageworm, Pieris rapae (Linnaeus). Credits: James Castner, University of Florida

\section{Damage}

Cabbageworms feed on foliage, and if left unchecked often will reduce mature plants to stems and large veins. Although they prefer leafy foliage, larvae may burrow into the heads of broccoli and cabbage, especially as they mature. Larvae are often immobile, and difficult to dislodge, and may be overlooked when cleaning produce. Larvae produce copious quantities of fecal material which also contaminate and stain produce.

\section{Host Plants}

Larvae of this insect feed widely on plants in the family Cruciferae, but occasionally on a few other plant families that contain mustard oils. Commonly attacked are vegetable crops such as broccoli, Brussels sprouts, cabbage, cauliflower, collard, horseradish, kale, and kohlrabi. Also sometimes attacked are flowers such as nasturtium and sweet alyssum, and weeds in the family Cruciferae. Adults 
sip nectar from flowers, and are commonly seen feeding at a number of plants.

\section{Natural Enemies}

The imported cabbageworm is subject to numerous predators, parasitoids, and diseases. General predators such as shield bugs (Hemiptera: Pentatomidae), ambush bugs (Hemiptera: Phymatidae), and vespid wasps (Hymenoptera: Vespidae) attack them, as do many insectivorous birds. Apanteles glomeratus (L.) (Hymenoptera: Braconidae) attacks the early instars, and emerges from the mature larva as it prepares to pupate. $A$. glomeratus is readily observed in the field, searching diligently on foliage for larvae. Dead cabbageworm larvae are often found with clusters of 20 to $30 \mathrm{~A}$. glomeratus cocoons attached. In some areas tachinids (Diptera: Tachinidae) are more important than wasps.

Virus and fungal diseases of imported cabbageworm have been reported, but the predominant natural disease in a granulosis virus (GV). P. rapae GV occurs most commonly under high density conditions, and often among late instar larvae after they have consumed the exterior foliage of plants and are forced into close contact. Over $90 \%$ mortality of larvae due to natural occurrence of this disease has been reported. In the early stages of infection, larvae are inactive and paler in color. As the disease progresses, the caterpillar body turns yellow, and tends to appear bloated. After death, the body blackens, the integument ruptures, and the liquefied body contents ooze on the plant foliage. Rainfall has a major roll in assisting the spread of the virus on the plant, and from the soil to the plant.

\section{Management}

Sampling: Harcourt (1962) studied the distribution of imported cabbageworm on crops. He suggested that one-half of each plant be examined visually for various stages. Recommended sample sizes were 20 plants for eggs, 30 for young larvae, 40 for mid-age larvae, 50 for large larvae, and 70 for pupae. Larvae often rest along the principal leaf vein, and are very difficult to see, because their body color closely matches the background. The presence of butterflies, which are highly visible, suggests future problems.

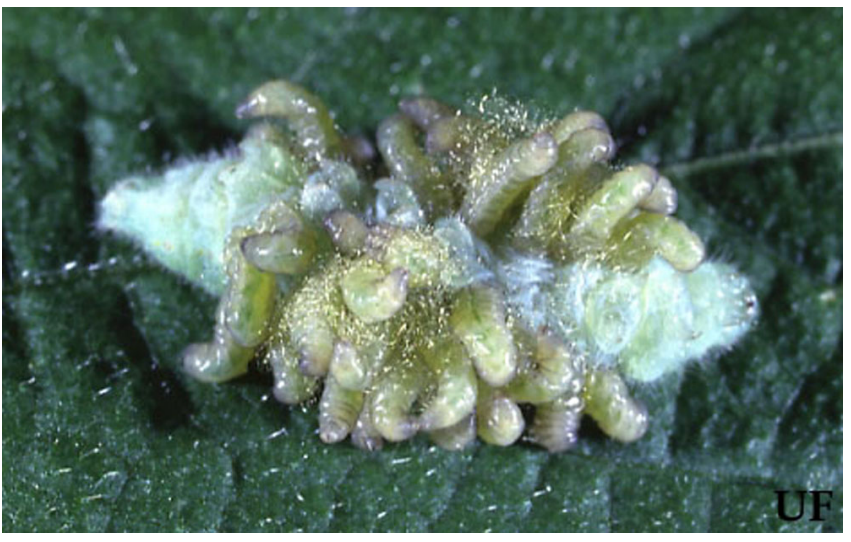

Figure 3. Parasitoid larvae emerging from a dead larva of the imported cabbageworm, Pieris rapae (Linnaeus). Credits: J. L. Capinera, University of Florida

\section{Insecticides}

Imported cabbageworm are readily killed by foliar application of insecticides, including the bacterial insecticide Bacillus thuringiensis. Botanical insecticides are fairly effective against cabbageworm, although dust formulations seem to be superior to aqueous sprays.

For more information see: Insect Management Guide for Vegetables

(http://edis.ifas.ufl.edu/MENU_IG:Vegetables)

\section{Biological Control}

Several microbes have been investigated for control of imported cabbageworm, and have the potential to be developed as microbial insecticides. The imported cabbageworm granulosis virus (Pieris rapae $\mathrm{GV}$ ) suppressed cabbageworm larvae in the laboratory and in a field test, but required four to 10 days to inflict mortality and was not superior to control provided by Bacillus thuringiensis. Home gardeners sometimes collect dying virus-infected caterpillars, macerate them in water, and spray the suspension onto cabbages as a home-made biological insecticide

\section{Host Plant Resistance}

Crucifer crops differ is their susceptibility to attack by imported cabbageworm. Chinese cabbage, turnip, mustard, rutabaga, and kale are less preferred than cabbage, collards, Brussels sprouts, broccoli, and cauliflower. Some cultivars of certain crops also have moderate levels of resistance to infestation by 
imported cabbageworm. One resistance character is due to, or correlated with, dark green, glossy leaves. This character imparts resistance to imported cabbageworm and other caterpillars, but increases susceptibility to flea beetle injury (Dickson and Eckenrode 1980). The red color found in many crucifer varieties also affects imported cabbageworm. Cabbage butterflies avoid ovipositing on red cabbage varieties (Radcliffe and Chapman 1966). However, larval survival is favored by red cabbage. Thus, while important genetic material has been identified, in most cases existing varieties are not a practical solution to caterpillar problems.

\section{Cultural Practices}

Paper caps early in the season, and row covers later, are effective in preventing oviposition by imported cabbageworm butterflies.

\section{Selected References}

Capinera, J.L. 2001. Handbook of Vegetable Pests. Academic Press, San Diego. 729 pp.

Chittenden, F.H. 1916a. The common cabbage worm. USDA Farmers' Bull. 766. 16 pp.

Dickson, M.H. and C.J. Eckenrode. 1980. Breeding for resistance in cabbage and cauliflower to cabbage looper, imported cabbageworm, and diamondback moth. J. Am. Soc. Hort. Sci. 105:782-785.

Harcourt, D.G. 1962. Design of a sampling plan for studies on the population dynamics of the imported cabbageworm, Pieris rapae (L.) (Lepidoptera: Pieridae). Can. Entomol. 94:849-859.

Harcourt, D.G. 1963a. Biology of cabbage caterpillars in eastern Ontario. Proc. Entomol. Soc. Ontario. 93:61-75

Radcliffe, E.B. and R.K. Chapman. 1966. Varietal resistance to insect attack in various cruciferous crops. J. Econ. Entomol. 59:120-125.

Richards, O.W. 1940. The biology of the small white butterfly (Pieris rapae), with special reference to the factors controlling its abundance. J. Anim. Ecol. 9:243-288. 